\title{
PENGARUH PASIR PANTAI SIPELOT SEBAGAI PENGGANTI AGREGAT 0/5 CAMPURAN HOT ROLLED SHEET - WEARING COURSE (HRS-WC)
}

\author{
Galang Setiyo, Bambang Wedyantadji ${ }^{2}$, Vega Aditama ${ }^{3}$ \\ 123) Jurusan Teknik Sipil S-1 Institut Teknologi Nasional Malang \\ Email : galangsetiyo86@gmail.com ${ }^{1}$
}

\begin{abstract}
Equitable infrastructure development continues to experience growth not only in Java but throughout Indonesia, especially in road construction. requires alternative materials of other natural sources in order to always meet the needs in road construction. Beach sand can affect the parameter values of the Marshall Test characteristics. Therefore, this study is expected to produce a better mixture of HRS-WC pavements. The research method used was experimental which was carried out at the Civil Engineering Construction Materials Laboratory of the National Institute of Technology Malang from February to May 2020. This study used variations in the levels of Sipelot Beach Sand of 25\%, 50\%, 75\%, 100\%, to find the optimum percentage., in terms of the Marshall characteristic value. Based on the results of testing Sipelot beach sand as a substitute for aggregate 0/5 in the Hot Rolled Sheet-Wearing Course (HRS-WC) mixture with beach sand variations of 25\%, 50\%, 75\% and $100 \%$ affect the Marshall characteristic values. Hypothesis testing for stability, VIM, VMA, MQ and VFA obtained Fcount> Ftable and it can be stated that there is a significant effect by adding variations in beach sand, while for flow there is no significant effect. The optimum percentage of use of beach sand was obtained at a variation of $37.63 \%$ with a stability value of $1178.93 \mathrm{~kg}$, flow $3.53 \mathrm{~mm}$, VIM 4.88\%, VMA $19.78 \%$, VFA $75.34 \%$, and Marshall Quetient 335.20 Kg/ mm.
\end{abstract}

Keywords : Hot Rolled Sheet-Wearing Course, Marshall Method, Sand Beach.

\begin{abstract}
ABSTRAK
Pemerataan pembangunan infrastruktur terus mengalami pertumbuhan tidak hanya di Pulau Jawa saja tetapi diseluruh wilayah Indonesia, khususnya pada pembangunan jalan raya. membutuhkan bahan alternatif sumber alam lainnya agar selalu memenuhi kebutuhan dalam pembangunan jalan raya. Pasir Pantai dapat mempengaruhi nilai parameter karakteristik Marshall Test. oleh karena itu penelitian ini diharapkan menghasilkan campuran perkerasan HRS-WC yang lebih baik. Metode penelitian yang digunakan adalah eksperimental yang dilakukan di Laboratorium Bahan Konstruksi Teknik Sipil Institut Teknologi Nasional Malang pada Februari hingga Mei 2020. Pada penelitian ini menggunakan variasi kadar Pasir Pantai Sipelot 25\%, 50\%, 75\%, 100\%, untuk mencari persentase yang optimum, ditinjau dari nilai karakteristik Marshall. Berdasarkan hasil pengujian pasir pantai Sipelot sebagai pengganti agregat 0/5 pada campuran Hot Rolled Sheet-Wearing Course (HRS-WC) dengan variasi pasir pantai 25\%, 50\%, 75\% dan 100\% mempengaruhi nilai karakteristik Marshall. Pengujian hipotesis untuk Stabilitas, VIM, VMA, MQ dan VFA didapatkan Fhitung > Ftabel dan dapat dinyatakan adanya pengaruh yang signifikan dengan penambahan variasi pasir pantai, sedangkan untuk flow tidak ada pengaruh yang signifikan. Persentase optimum penggunaan pasir pantai diperoleh pada variasi $37,63 \%$ dengan nilai stabilitas 1178,93 Kg, flow 3,53 mm, VIM 4,88\%, VMA 19,78\%, VFA 75,34\%, dan Marshall Quetient 335,20 Kg/mm.
\end{abstract}

Kata kunci : Hot Rolled Sheet-Wearing Course, Metode Marshall, Pasir Pantai.

\section{PENDAHULUAN}

Pemerataan pembangunan infrastruktur terus mengalami pertumbuhan tidak hanya di Pulau Jawa saja tetapi diseluruh wilayah Indonesia, khususnya pada pembangunan jalan raya. Dari data Kementrian Pekerjaan Umum dan Dinas Pekerjaan Umum Pemerintah Prov/Kab/Kota Panjang jalan menurut jenis permukaannya tahun 2017 jalan ber-aspal mencapai $321.093 \mathrm{~km}$, jalan tidak ber-aspal mencapai $218.260 \mathrm{~km}$, sehingga total Panjang jalan pada tahun 2017 adalah $539.353 \mathrm{~km}$ dan akan terus mengalami pertumbuhan seiring meningkatnya kebutuhan sarana transportasi untuk mempermudah masyarakat melakukan segala kegiatan social dan ekonomi sehari harinya sehingga membutuhkan bahan alternatif sumber alam lainnya agar selalu memenuhi kebutuhan dalam pembangunan jalan raya. Pasir 
pantai adalah jenis pasir yang didapatkan dari pesisir pantai. Pasir pantai yang memiliki butiran halus berkisar 0,55-2.5 mm, berbeda dengan pasir darat yang rata-rata antara $0.55-3 \mathrm{~mm}$. Hal ini karena pasir pantai terbentuk akibat pengikisan batu yang disebabkan erosi gelombang laut, sedangkan pasir darat berasal dari pecahan batu atau diambil dari sungai. Pasir pantai harus dimanfaatkan sebaikbaiknya pada campuran aspal, Hal ini adalah upaya dalam mencari material alternatif mengatasi sumber agregat yang semakin hari semakin terbatas untuk di dapatkan di wilayah-wilayah tertentu di Indonesia, karena pembangunan Infrastruktur yang semakin pesat. Pasir pantai yang di gunakan berasal dari pantai Sipelot Desa Pujiharjo, Kecamatan Tirtoyudo, Kabupaten Malang, Provinsi Jawa Timur.

Dari beberapa permasalahan diatas, diketahui bahwa pasir pantai digunakan sebagai material alternatif dan diharapkan dapat meningkatkan kualitas campuran aspal terutama nilai karakteristik Marshall. Maka rumusan yang dapat diambil yaitu mencari persentase yang optimum, ditinjau dari nilai karakteristik Marshall

\section{TINJAUAN PUSTAKA}

\section{Lapisan Beton Aspal}

Beton Aspal (Hotmix) merupakan campuran agregat kasar, agregat halus, dan bahan pengisi (filler) dengan bahan pengikat aspal dengan kondisi suhu tinggi dengan komposisi yang diteliti dan diatur oleh spesifikasi teknis. Campuran aspal panas adalah suatu campuran perkerasan jalan lentur yang terdiri dari agregat kasar, agregat halus, filler, dan bahan pengikat aspal dengan perbandingan tertentu dan dicampur dalam kondisi panas.

Tabel 1. Nominal Minimum Campuran

\begin{tabular}{|c|c|c|c|}
\hline & Jenis Campuran & Simbol & $\begin{array}{l}\text { Tebal Nominal } \\
\text { Menimum (cm) }\end{array}$ \\
\hline \multicolumn{2}{|c|}{ Latasir Kelas A } & SS-A & 1,5 \\
\hline \multicolumn{2}{|c|}{ Latasir Kelas B } & SS-B & 2,0 \\
\hline \multicolumn{2}{|c|}{ Lap. Tippos Abu Batu } & STS & 1,5 \\
\hline \multicolumn{2}{|c|}{ Lap. Tipes Abu Batu Kasar } & STK & 2,0 \\
\hline \multirow[t]{2}{*}{ Latastoe } & Lapis Permukasn & HRS-A & 3,0 \\
\hline & Lapis Pondasi & HRS-B & 3,5 \\
\hline \multirow[t]{2}{*}{ Laston } & Lapis Permukaan & AC & 4,0 \\
\hline & Lapis Pondasi & ATB & 5,0 \\
\hline
\end{tabular}

\section{Karakteristik Beton Aspal}

Terdapat tujuh karakteristik campuran yang harus dimiliki oleh beton aspal yaitu stabilitas, keawetan, kelenturan atau fleksibilitas, ketahanan terhadap kelelahan (fatique resistance), kekesatan permukaan atau ketahanan geser, kedap air dan kemudahan pelaksanaan (workability).

\section{Hot Rolled Sheet - WC (HRS-WC)}

Lataston merupakan lapisan permukaan yang terdiri dari campuran antara agregat bergradasi timpang, mineral pengisi (Filler), dan aspal IP 60 atau 80 yang dicampur dalam keadaan panas dengan tebal padat antara 2,5 $-3 \mathrm{~cm}$. Filler atau material pengisi yang sering digunakan adalah abu batu, kapur padam, semen portland, atau bahan non plastis lainnya yang lolos ayakan No.200 sama atau lebih besar dari 75\% berat filler abu batu. Lataston terdiri dari dua macam campuran yaitu lataston lapis pondasi (HRS - Base) dan lataston permukaan (HRS - WC) dengan ukuran maksimum agregat masing-masing campuran adalah $19 \mathrm{~mm}$. HRS - Base mempunyai proporsi fraksi agregat kasar lebih besar dari pada HRS - WC

Tabel 2. Ketentuan Sifat Campuran HRS

\begin{tabular}{|c|c|c|c|}
\hline \multirow{2}{*}{\multicolumn{2}{|c|}{ Sffa-sifat Campuna }} & \multicolumn{2}{|c|}{ Lataston } \\
\hline & & \multirow{2}{*}{$\frac{\text { Lapis Ass }}{59}$} & \multirow{2}{*}{$\frac{\text { Lapis Fondasi }}{5.5}$} \\
\hline Kadr aspol cfoldif (8) & Min & & \\
\hline Jumbah tuntedan per boiting & & \multicolumn{2}{|c|}{50} \\
\hline \multirow{2}{*}{ Rongge dalan campunn $\left(\gamma_{0}\right)^{\text {it }}$} & Min & \multicolumn{2}{|c|}{+0} \\
\hline & Mals & \multicolumn{2}{|c|}{60} \\
\hline Ronsel dalan Aosed (VMA) (\%) & Min & 18 & 17 \\
\hline Ronega terisi aspal( $\mathbf{( 5 )}$ & Min & \multicolumn{2}{|c|}{68} \\
\hline Strbilitas Mantall (kg) & Min & \multicolumn{2}{|c|}{600} \\
\hline Marshall Qwotikn (be/mn) & Min & \multicolumn{2}{|c|}{250} \\
\hline 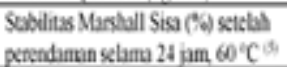 & Min & \multicolumn{2}{|c|}{90} \\
\hline
\end{tabular}

Tabel 3. Gradasi Agregat Untuk Campuran Aspal

\begin{tabular}{|c|c|c|c|c|c|c|c|c|}
\hline \multicolumn{2}{|c|}{$\begin{array}{l}\text { Uheras } \\
\text { Sariogan }\end{array}$} & \multicolumn{7}{|c|}{ Peryen Berat Loles } \\
\hline (mn) & (ASTM) & SS & STS & STK & HRS-A & HRS.B & $\mathrm{AC}$ & ATB \\
\hline 37,5 & $1,5^{\circ}$ & - & - & - & - & - & - & - \\
\hline 25,0 & $I^{\prime \prime}$ & . & . & . & . & - & . & 100 \\
\hline 19,0 & $3 / 4^{\circ}$ & - & - & - & 100 & 109 & 100 & $90 \cdot 100$ \\
\hline 127 & WE & - & $\cdot$ & 100 & $80-100$ & $75-100$ & $90-100$ & $65-90$ \\
\hline 9,5 & $3 / s^{\circ}$ & 100 & 100 & $95 \cdot 100$ & $60-85$ & $57-80$ & $60-85$ & $55-80$ \\
\hline 4,75 & in & $95-100$ & $95-100$ & $75 \cdot 100$ & $58-80$ & $48-75$ & $38-55$ & $35-60$ \\
\hline 2,36 & 178 & 70.95 & $80-95$ & $55 \cdot 90$ & $53 \cdot 78$ & $38 \cdot 70$ & $27-40$ & $24-45$ \\
\hline 1.18 & 116 & $45-80$ & $60 \cdot 85$ & $4-80$ & $40-70$ & $29-60$ & $17 \cdot 30$ & $15 \cdot 34$ \\
\hline 0,600 & $\$ 30$ & $30 \cdot 65$ & $45=74$ & $32 \cdot 70$ & $25 \cdot 60$ & 19.47 & $14-24$ & $9-25$ \\
\hline 0,300 & $\$ 50$ & $22-50$ & $30 \cdot 62$ & $20-60$ & $13-48$ & $12-35$ & $9-18$ & $5-17$ \\
\hline Q.150 & $\$ 100$ & $19-34$ & $16=40$ & $12-50$ & $8-30$ & $6-25$ & $5-12$ & $3-12$ \\
\hline 0,075 & $\$ 200$ & $6-18$ & $6-18$ & $6-12$ & $5-10$ & $5-9$ & 2.8 & 2.9 \\
\hline
\end{tabular}

Aspal

Aspal adalah material utama pada konstruksi lapis permukaan lentur (flexible pavement) jalan raya, yang berfungsi sebagai bahan pengikat karena mempunyai daya lekat yang kuat, mempunyai sifat adhesif, kedap air dan mudah dikerjakan. 


\section{Pasir Pantai}

Pasir pantai adalah jenis pasir yang didapatkan dari pesisir pantai yang memiliki butiran halus berkisar 0,55-2,5 mm. Pasir pantai umumnya merujuk pada logam berat seperti biji besi dan timah yang terkandung. Kandungan mineral pada pasir pantai biasanya ditemukan di daerah aluvial, seperti aliran sungai atau laut yang terhubung dengan sumber vulkanik. Di alam, pasir pantai ditemukan dengan kemurnian yang bervariasi tergantung pada proses terbentuknya disamping adanya material lain yang ikut selama proses pengendapan. Material dengan unsur yang dominan berkontribusi sebagai pemberi warna pada pasir pantai dan warna tersebut dapat diperkirakan derajat kemurniannya. Salah satu kandungan pasir pantai adalah kalsium.

\section{Pengujian Marhsall}

Pengujian marshall dimaksudkan dengan tujuan untuk menentukan ketahanan/stabilitas terhadap kelelehan plastis/flow dari campuran aspal agregat, kelelehan plastis/flow adalah keadaan perubahan bentuk suatu campuran aspal yang terjadi akibat suatu beban sampai batas runtuh yang dinyatakan dalam milimeter atau 0.01 inch. serta analisa kepadatan dan pori dari campuran padat yang terbentuk. Pengujian ini menghasilkan sejumlah data parameter Marshall dan terdiri dari Stabilitas, Flow, rongga antar butir agregat (VMA), rongga dalam campuran (VIM), rongga terisi bitumen (VFB), dan Marshall Quotient (MQ).

\section{Pengolahan Data}

Setelah data berhasil dikumpulkan menggunakan teknik pengumpulan data yang tepat, kegiatan selanjutnya adalah mengolah atau menganalisis data. Pengolahan atau analisis data dapat dilakukan secara kualitatif atau kuantitatif.

\section{METODE PENELITIAN}

Rancangan penelitian dibuat untuk menyusun penelitian yang akan dilakukan sehingga dalam pelaksanaan penelitian nantinya dapat terarah sesuai dengan apa yang telah direncanakan. Berikut Rancangan penelitian yang dilakukan :

1. Studi Pustaka

Studi putaka bertujuan untuk mengkaji hubungan variabel yang akan diteliti dengan mempelajari teori-teori yang ada untuk merumuskan hipotesis penelitian. Sehingga didapatkan prosentase penggunaan Pasir Pantai sebagai bahan pengganti yaitu $25 \%$, 50\%, dan $75 \%$ terhadap KAO. Kemudian hasil yang diperoleh dianalisa, dievaluasi, dan ditarik kesimpulan.

2. Studi Eksperimen

Studi eksperimen dilakukan pengujian campuran HRS-WC (Hot Rolled Sheet - Wearing Course) di Laboratorium Bahan Kontruksi Institut
Teknologi Nasional Malang Jl. Bendungan Sigura-gura No. 2 Malang. untuk mendapatkan data-data yang diperlukan dan di analisa secara statistik untuk menguji hipotesa sehingga didapat kesimpulan akhir.

\section{Persiapan Bahan}

Bahan-bahan yang akan digunakan dalam penelitian ini antara lain:

1. Agregat 0/5, 5/10, 10/10 diambil dari AMP PT. Sriwijaya 87, Kabupaten Malang.

2. Agregrat $0 / 5$ berupa pasir pantai yang di ambil dari Pantai Sipelot, Desa Pujiharjo, Kecamatan Tirtoyudo, Kabupaten Malang, Provinsi Jawa Timur.

3. Bahan pengisi (filler) yang digunakan adalah Semen Gresik

4. Aspal yang digunakan adalah produksi Pertamina dengan penetrasi 60/70.

\section{Persiapan Alat}

Adapun alat-alat yang digunakan dalam penelitian ini semuanya terdapat didalam Laboratorium Bahan Kontruksi ITN Malang. Alat yang digunakan dalam penelitian ini adalah:

1. Seperangkat alat pengujian aspal

2. Seperangkat alat pengujian agregat

3. Seperangkat alat untuk metode marshall

\section{Proses Penelitian}

1. Perendaman Pasir Pantai Sipelot selama 4 hari untuk mengurangi kadar garam.

2. Penentuan kadar aspal rencana

Penelitian ini dilakukan dengan membuat perkiraan kadar aspal rencana $(\mathrm{P})$, sebanyak 5 variasi kadar aspal yang berbeda setiap 0,5\% dengan rincian 2 variasi kadar aspal di atas $\mathrm{P}$ $(+0,5 \% ;+1 \%)$ dan 2 variasi kadar aspal di bawah P (-0,5\%; -1\%) dengan masing-masing kadar aspal dibuat 3 benda uji. Setiap benda uji kemudian dipadatkan sebanyak 2x50 kali tumbukan (Spesifikasi Umum Bina Marga 2018). Rumus yang digunakan untuk menentukan kadar aspal rencana:

$\mathrm{P}=0,035(\mathrm{CA}+\mathrm{MA})+0,045(\mathrm{FA})+0,18$

$$
\text { (Filler) + Konstanta }
$$

3. Pembuatan Benda Uji

Pengumpulan benda uji dengan cara membuat sempel dengan mencetak benda uji berbentuk silinder dengan diameter $10,16 \mathrm{~cm}$ dan tinggi benda uji $6,35 \mathrm{~cm}$, dan dibutuhkan $\pm 1200 \mathrm{gr}$ campuran bahan untuk masing-masing benda uji. Benda uji ini dibuat melalui proses pemanasan, pengadukan, dan pemadatan antara campuran agregat dan aspal (sesuai dengan SNI 06-24891991). Sehingga didapatkan KAO (Kadar Aspal Optimum) pada campuran HRS - WC untuk selanjutnya digunakan dalam penambahan Aspal Buton. 
4. Analisis Data

Pada tahap ini semua data yang diperoleh dari hasil pengujian dianalisis untuk menentukan karakteristik marshall.

Tabel 4. Jumlah Sampel Benda Uji

\begin{tabular}{|c|c|c|c|c|c|c|}
\hline \multirow{2}{*}{ Pengujian } & \multicolumn{5}{|c|}{ Kadar Aspal \% } & \multirow{2}{*}{$\begin{array}{l}\text { Jumlah } \\
\text { Sampel }\end{array}$} \\
\hline & P-1 & $P=0.5$ & $\mathrm{P}$ & $\mathrm{P}+0.5$ & $\mathrm{P}+1$ & \\
\hline \multirow{2}{*}{$\begin{array}{c}\text { Penentuan Kadar } \\
\text { Aspal optimum } \\
\text { (100\% Batu Alam) } \\
\text { Penentuan Kadar } \\
\text { Aspal optimum } \\
\text { (100\% Pasir Pantai) }\end{array}$} & 3 & 3 & 3 & 3 & 3 & 15 \\
\hline & 3 & 3 & 3 & 3 & 3 & 15 \\
\hline \multirow{4}{*}{ KAO \% } & \multicolumn{6}{|c|}{ Variasi kadar agregat (Pasir Pantai) } \\
\hline & \multicolumn{2}{|c|}{$25 \%$} & 509 & \multicolumn{2}{|c|}{$75 \%$} & \multirow[b]{2}{*}{9} \\
\hline & \multicolumn{2}{|c|}{3} & 3 & \multicolumn{2}{|c|}{3} & \\
\hline & \multicolumn{5}{|c|}{ Total Benda Uji } & 39 \\
\hline
\end{tabular}

Berikut Flowchart penelitian :

Gambar . Diagram Alir Penelitian

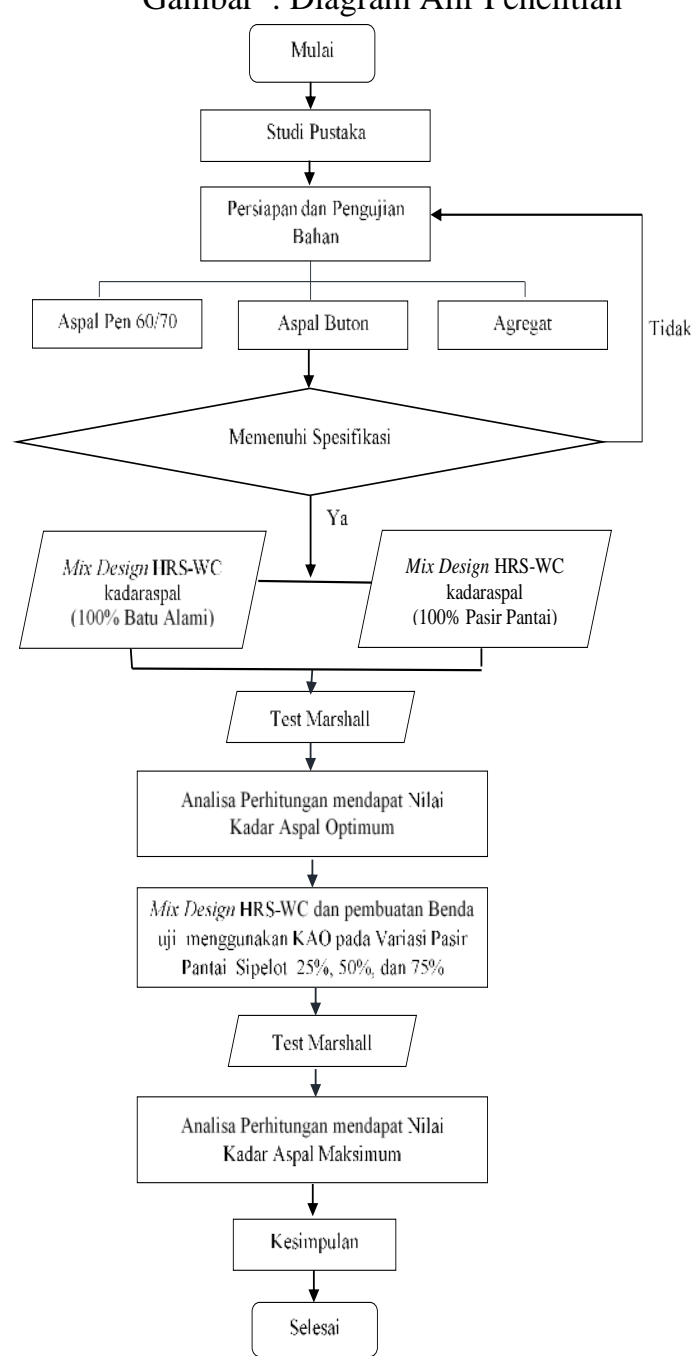

4. PEMBAHASAN

\section{Hasil Pengujian Agregat}

Dari hasil pengujian agrerat di Laboratorium diketahui bahwa agregat dari AMP Sriwijaya 87, Kendalpayak Kec. Pakisaji, Kab, Malang, Jawa Timur memenuhi Spesifikasi Umum Bina Marga 2018 untuk digunakan sebagai bahan material perkerasan jalan untuk campuran beraspal panas seperti pada tabel berikut ini:

Tabel 5. Hasil Pengujian Agregat

\begin{tabular}{|c|c|c|c|c|}
\hline No. & Pengujian & Hasil & $\begin{array}{l}\text { Spesifikasi Umum } \\
\text { Binda Marga } 2018\end{array}$ & Keterangan \\
\hline \multirow[t]{3}{*}{1} & $\begin{array}{l}\text { Berat Isi Agregrat } \\
10 / 10\end{array}$ & $1,43 \mathrm{gr} / \mathrm{cm}^{3}$ & & \\
\hline & & $1,48 \mathrm{gr} / \mathrm{cm}^{3}$ & & \\
\hline & & $1,49 \mathrm{gr} / \mathrm{cm}^{3}$ & & \\
\hline \multirow[t]{3}{*}{2} & Berat Isi Agregrat $5 / 10$ & $1,34 \mathrm{gr} / \mathrm{cm}^{3}$ & & \\
\hline & & $1,42 \mathrm{gr} / \mathrm{cm}^{3}$ & & \\
\hline & & $1,43 \mathrm{gr} / \mathrm{cm}^{3}$ & & \\
\hline \multirow[t]{3}{*}{3} & Berat Isi Agregrat 0/5 & $1,64 \mathrm{gr} / \mathrm{cm}^{3}$ & & \\
\hline & & $1,72 \mathrm{gr} / \mathrm{cm}^{3}$ & & \\
\hline & & $1,74 \mathrm{gr} / \mathrm{cm}^{3}$ & & \\
\hline 4 & $\begin{array}{l}\text { Angka Angularitas } \\
\text { Kasar }\end{array}$ & 2,27 & $0-12$ & Memenuhi \\
\hline \multirow[t]{2}{*}{5} & $\begin{array}{l}\text { Berat Jenis Agregrat } \\
10 / 10\end{array}$ & 2,65 & Min. 2,5 & Memenuhi \\
\hline & $\begin{array}{l}\text { Penyerapan Agregrat } \\
10 / 10\end{array}$ & $2,15 \%$ & Maks. $3 \%$ & Memenuhi \\
\hline \multirow[t]{2}{*}{6} & $\begin{array}{l}\text { Berat Jenis Agregrat } \\
5 / 10\end{array}$ & 2,60 & Min. 2,5 & Memenuhi \\
\hline & $\begin{array}{l}\text { Penyerapan Agregrat } \\
5 / 10\end{array}$ & $2,65 \%$ & Maks. $3 \%$ & Memenuhi \\
\hline \multirow[t]{2}{*}{7} & $\begin{array}{l}\text { Berat Jenis Agregrat } \\
0 / 5\end{array}$ & 2,60 & Min. 2,5 & Memenuhi \\
\hline & $\begin{array}{l}\text { Penyerapan Agregrat } \\
0 / 5\end{array}$ & $2,32 \%$ & Maks. $3 \%$ & Memenuhi \\
\hline 8 & Flakiness Kasar & $19,90 \%$ & Maks $25 \%$ & Memenuhi \\
\hline 9 & Impact Value & $9,39 \%$ & Maks. $30 \%$ & Memenuhi \\
\hline 10 & $\begin{array}{l}\text { Keausan Agregrat } \\
\text { Kasar }\end{array}$ & $23,72 \%$ & Maks. $40 \%$ & Memenuhi \\
\hline
\end{tabular}

\section{Hasil Pengujian Aspal}

Dari hasil pengujian agrerat di Laboratorium diketahui bahwa agregat dari AMP Sriwijaya 87, Kendalpayak Kec. Pakisaji, Kab, Malang, Jawa Timur memenuhi Spesifikasi Umum Bina Marga 2018 untuk digunakan sebagai bahan material perkerasan jalan untuk campuran beraspal panas seperti pada tabel berikut ini:

Tabel 6. Hasil Pengujian Aspal

\begin{tabular}{|c|l|cc|c|}
\hline No. & \multicolumn{1}{|c|}{ Pengujian } & \multicolumn{2}{|c|}{ Hasil } & $\begin{array}{c}\text { Spesifikasi Umum } \\
\text { Bina Marga 2018 }\end{array}$ \\
\hline 1 & $\begin{array}{l}\text { Penetrasi Sebelum } \\
\text { Kehilangan Berat }\end{array}$ & 69,70 & $10^{-1} \mathrm{~mm}$ & $60-70$ \\
\hline 2 & $\begin{array}{l}\text { Penetrasi Setelah } \\
\text { Kehilangan Berat }\end{array}$ & 68,60 & $10^{-1} \mathrm{~mm}$ & Min. 54 \\
\hline 3 & $\begin{array}{l}\text { Titik Nyala dan Titik } \\
\text { Bakar Aspal }\end{array}$ & $314 / 319$ & ${ }^{\circ} \mathrm{C}$ & Min. 232 \\
\hline 4 & $\begin{array}{l}\text { Titik Lembek Aspal } \\
\text { dan Ter } \\
\text { Sebelum Kehilangan } \\
\text { Berat }\end{array}$ & 54,5 & ${ }^{\circ} \mathrm{C}$ & Min. 48 \\
\hline 5 & $\begin{array}{l}\text { Titik Lemebk Aspal } \\
\text { dan Ter } \\
\text { Setelah Kehilangan } \\
\text { Berat }\end{array}$ & 53,5 & ${ }^{\circ} \mathrm{C}$ & Min. 48 \\
\hline 6 & $\begin{array}{l}\text { Berat Jenis Aspal } \\
\text { Keras }\end{array}$ & 1,06 & $\mathrm{gr} / \mathrm{cm}^{2}$ & Min. 1 \\
\hline 7 & $\begin{array}{l}\text { Kehilangan Berat } \\
\text { Minyak }\end{array}$ & 0,187 & $\%$ & Maks. 0,8 \\
\hline 8 & $\begin{array}{l}\text { Daktilitas Sebelum } \\
\text { Kehilangan Berat }\end{array}$ & 150 & $\mathrm{~cm}$ & Min. $100 \mathrm{~cm}$ \\
\hline 9 & $\begin{array}{l}\text { Daktilitas Setelah } \\
\text { Kehilangan Berat }\end{array}$ & 133,75 & $\mathrm{~cm}$ & Min. $100 \mathrm{~cm}$ \\
\hline
\end{tabular}

Hasil Pengujian Pasir Pantai Sipelot 
Jurnal Sondir

Program Studi Teknik Sipil S1, ITN MALANG

Dari hasil pengujian Pasir Pantai Sipelot yang di uji di Laboratorium Bahan Konstruksi, Program Studi Teknik Sipil, Institut Teknologi Nasional Malang, Jalan Bendungan Sigura - gura No.2 Malang, Jawa Timur. Pasir Pantai Sipelot didapat kan berat jenisnya sebesar 2,68\% dan penyerapan sebesar 1,40\% yang mana telah memenuhi persyaratan.

Tabel 7. Hasil Analisa Saringan Aspal Buton

\begin{tabular}{|c|c|c|c|c|c|c|}
\hline \multirow{2}{*}{\multicolumn{3}{|c|}{ Ukuran saringan }} & \multirow{3}{*}{$\begin{array}{c}\text { Berat tertahan } \\
\text { (eram) } \\
0.0\end{array}$} & \multirow{3}{*}{$\begin{array}{c}\text { Kumulatif } \\
\text { (gram) } \\
0.00\end{array}$} & \multicolumn{2}{|c|}{ Prosentase } \\
\hline & & & & & \multirow{2}{*}{$\begin{array}{c}\text { tettahan } \\
0.00\end{array}$} & \multirow{2}{*}{$\frac{\text { Lolos }}{100.00}$} \\
\hline 25 & $\mathrm{~mm}$ & (1") & & & & \\
\hline 19 & $\mathrm{~mm}$ & $\left(3 / 4^{\prime \prime}\right)$ & 0.0 & 0.00 & 0.00 & 100.00 \\
\hline 12.5 & $\mathrm{~mm}$ & $\left(1 / 2^{\prime \prime}\right)$ & 0.0 & 0.00 & 0.00 & 100.00 \\
\hline 9.5 & $\mathrm{~mm}$ & $\left(3 / 8^{\prime \prime}\right)$ & 0.0 & 0.00 & 0.00 & 100.00 \\
\hline 4.75 & $\mathrm{~mm}$ & (No. 4) & 9.5 & 9.50 & 0.48 & 99.52 \\
\hline 2.36 & $\mathrm{~mm}$ & (No. 8) & 237.2 & 246.70 & 12.34 & 87.66 \\
\hline 2 & $\mathrm{~mm}$ & (No. 10) & 75.4 & 322.10 & 16.11 & 83.89 \\
\hline 1.18 & $\mathrm{~mm}$ & (No. 16) & 188.8 & 510.90 & 25.55 & 74.45 \\
\hline 0.71 & $\mathrm{~mm}$ & (No. 25) & 354.5 & 865.40 & 43.27 & 56.73 \\
\hline 0.6 & $\mathrm{~mm}$ & (No. 30) & 227.7 & 1093.10 & 54.66 & 45.34 \\
\hline 0.425 & $\mathrm{~mm}$ & (No. 40) & 192.3 & 1285.40 & 64.28 & 35.72 \\
\hline 0.28 & $\mathrm{~mm}$ & (No. 50) & 221.2 & 1506.60 & 75.34 & 24.66 \\
\hline 0.15 & $\mathrm{~mm}$ & (No. 100) & 129.8 & 1636.40 & 81.83 & 18.17 \\
\hline 0.075 & & (No. 200) & 215.9 & 1852.30 & 92.62 & 7.38 \\
\hline & pan & & 147.5 & 1999.80 & 100.00 & 0.00 \\
\hline & Total ber & & 1999.80 & & & \\
\hline
\end{tabular}

Tabel 8. Hasil Pengujian Pasir Pantai Sipelot

\begin{tabular}{|c|c|c|c|c|}
\hline No. & Pengujian & Hasil & $\begin{array}{c}\text { Spesifikasi Bina } \\
\text { Bina Marga }\end{array}$ & Keterangan \\
\hline 1 & Berat isi Agregat 10/20 & - & & \\
\hline & & - & & \\
\hline & & - & & \\
\hline 2 & Berat isi Agregat 10/10 & 1.43 & & \\
\hline & & 1.48 & & \\
\hline & & 1.49 & & \\
\hline 3 & Berat isi Agregat 5/10 & 1.34 & & \\
\hline & & 1.42 & & \\
\hline & & 1.43 & & \\
\hline 4 & Berat isi Agregat 0/5 & 1.72 & & \\
\hline & & 1.75 & & \\
\hline & & 1.71 & & \\
\hline 5 & Berat Jenis Agregat 10/10 & 2.65 & Min. 2.5 & Memenuhi \\
\hline & Penyerapan Agregat 10/10 & $2.15 \%$ & Maks 3\% & Memenuhi \\
\hline 6 & Berat Jenis Agregat 5/10 & 2.60 & Min. 2.5 & Memenuhi \\
\hline & Penyerapan Agregat 5/10 & $2.65 \%$ & Maks 3\% & Memenuhi \\
\hline 7 & Berat Jenis Agregat 0/5 & 2.68 & Min. 2.5 & Memenuhi \\
\hline & Penyerapan Agregat 0/5 & $1.40 \%$ & Maks 3\% & Memenuhi \\
\hline 8 & Angka Angularitas Kasar & 2.27 & $0-12$ & Memenuhi \\
\hline 9 & Flakiness & 19.90 & Maks 25\% & Memenuhi \\
\hline 10 & Impact Value & 9.39 & Maks 30\% & Memenuhi \\
\hline 11 & Abrasi & 23.72 & Maks 30\% & Memenuhi \\
\hline
\end{tabular}

\section{Hasil Analisa Saringan Agregat 10/10, Agregat} 5/10, dan Agregat 0/5 Batu Pecah

Tahap rancangan campuran di Laboratorium dilaksanakan setelah pemeriksaan apakah agregat dan aspal yang akan dipergunakan memenuhi spesifikasi material campuran. Hasil pengujian analisa saringan yang sudah dilakukan pengujian yaitu agregat 10/10, $5 / 10$ dan $0 / 5$ selanjutnya didapatkan presentase lolos yang akan digunakan dalam mix design untuk mencari komposisi campuran.
Tabel 9. Saringan digunakan untuk Campuran HRS-WC Agregrat 10/10

\begin{tabular}{|c|c|c|c|c|}
\hline \multirow{2}{*}{ Uku uran sa ringan } & \multirow{2}{*}{$\begin{array}{c}\text { Berat tertahan } \\
\text { (gram) }\end{array}$} & \multirow{2}{*}{$\begin{array}{l}\text { Kumulatif } \\
\text { (gram) }\end{array}$} & \multicolumn{2}{|c|}{ Prosentase } \\
\hline & & & tertahan & Lolos \\
\hline $19 \mathrm{~mm} \quad\left(3 / 4^{\prime \prime}\right)$ & 0 & 0 & 0,00 & 100,00 \\
\hline $12,5 \mathrm{~mm} \quad(1 / 2 ")$ & 125,1 & 125.1 & 1,253 & 98,75 \\
\hline $9,5 \mathrm{~mm} \quad\left(3 / 8^{\prime \prime}\right)$ & 6795,9 & 6921 & 69,3 & 30,7 \\
\hline $4,75 \mathrm{~mm} \quad$ (No. 4) & 2475 & 9396 & 94,08 & 5,917 \\
\hline $2,36 \mathrm{~mm} \quad$ (No. 8) & 387,8 & 9784 & 97,97 & 2,034 \\
\hline $1,18 \mathrm{~mm} \quad$ (No. 16) & 130 & 9914 & 99,27 & 0,732 \\
\hline $0,6 \mathrm{~mm} \quad$ (No. 30) & 3,3 & 9917 & 99,3 & 0,699 \\
\hline $0,28 \mathrm{~mm}$ & 13,7 & 9931 & 99,44 & 0,562 \\
\hline $0,15 \mathrm{~mm} \quad$ (No. 100) & 13,6 & 9944 & 99,57 & 0,426 \\
\hline $0,075 \mathrm{~mm} \quad$ (No. 200) & 25,9 & 9970 & 99,83 & 0,166 \\
\hline pan & 16,6 & 9987 & 100 & 0 \\
\hline Total berat & 9986.9 & & & \\
\hline
\end{tabular}

Tabel 10. Saringan digunakan untuk Campuran HRS-WC Agregrat 5/10

\begin{tabular}{|c|c|c|c|c|c|c|}
\hline \multirow{2}{*}{\multicolumn{3}{|c|}{ Ukuran saringan }} & \multirow{3}{*}{$\begin{array}{c}\begin{array}{c}\text { Berat } \\
\text { tertahan } \\
\text { (gram) }\end{array} \\
0\end{array}$} & \multirow{3}{*}{$\begin{array}{c}\text { Kumulatif } \\
\text { (gram) }\end{array}$} & \multicolumn{2}{|c|}{ Prosentase } \\
\hline & & & & & \multirow{2}{*}{$\begin{array}{c}\text { tertahan } \\
0\end{array}$} & \multirow{2}{*}{$\begin{array}{r}\text { Lolos } \\
100\end{array}$} \\
\hline 19 & $\mathrm{~mm}$ & $\left(3 / 4^{\prime \prime}\right)$ & & & & \\
\hline 12,5 & $\mathrm{~mm}$ & $\left(1 / 2^{\prime \prime}\right)$ & 0 & 0 & 0 & 100 \\
\hline 9,5 & $\mathrm{~mm}$ & $\left(3 / 8^{\prime \prime}\right)$ & 3583.8 & 3584 & 35,87 & 64,13 \\
\hline 4,75 & $\mathrm{~mm}$ & (No. 4) & 3556 & 7140 & 71,47 & 28,53 \\
\hline 2,36 & $\mathrm{~mm}$ & (No. 8) & 1760 & 8900 & 89,09 & 10,91 \\
\hline 1,18 & $\mathrm{~mm}$ & (No. 16) & 877,9 & 9778 & 97,87 & 2,125 \\
\hline 0,6 & $\mathrm{~mm}$ & (No. 30) & 123,5 & 9901 & 99,11 & 0,889 \\
\hline 0,28 & $\mathrm{~mm}$ & (No. 50) & 14.1 & 9916 & 99,25 & 0,748 \\
\hline 0,15 & $\mathrm{~mm}$ & (No. 100) & 15.3 & 9931 & 99,41 & 0,595 \\
\hline 0,075 & $\mathrm{~mm}$ & (No. 200) & 25.9 & 9957 & 99,66 & 0,335 \\
\hline & & an & 33,5 & 9990 & 100 & 0 \\
\hline & tal be: & & 9990,2 & & & \\
\hline
\end{tabular}

Tabel 11. Saringan digunakan untuk Campuran HRS-WC Agregrat Halus 0/5

\begin{tabular}{|c|c|c|c|c|c|c|}
\hline \multirow{2}{*}{\multicolumn{3}{|c|}{ Ukuran saringan }} & \multirow{3}{*}{$\begin{array}{c}\text { Berat tertahan } \\
\text { (gram) } \\
0\end{array}$} & \multirow{3}{*}{$\begin{array}{c}\text { Kumulatif } \\
\text { (gram) }\end{array}$} & \multicolumn{2}{|l|}{ Prosentase } \\
\hline & & & & & \multirow{2}{*}{$\begin{array}{c}\text { tertahan } \\
0\end{array}$} & \multirow{2}{*}{$\begin{array}{r}\text { Lolos } \\
100\end{array}$} \\
\hline 19 & $\mathrm{~mm}$ & $\left(3 / 4^{\prime \prime}\right)$ & & & & \\
\hline 12,5 & $\mathrm{~mm}$ & $(1 / 2 ")$ & 0 & 0 & 0 & 100 \\
\hline 9,5 & $\mathrm{~mm}$ & $(3 / 8 ")$ & 0 & 0 & 0 & 100 \\
\hline 4,75 & $\mathrm{~mm}$ & (No. 4) & 9.8 & 9.8 & 0,49 & 99,51 \\
\hline 2,36 & $\mathrm{~mm}$ & (No. 8) & 190,1 & 199,9 & 9,997 & 90 \\
\hline 1,18 & $\mathrm{~mm}$ & (No. 16) & 535,1 & 735 & 36,76 & 63,24 \\
\hline 0,6 & $\mathrm{~mm}$ & (No. 30) & 305,2 & 1040 & 52,02 & 47,98 \\
\hline 0,28 & $\mathrm{~mm}$ & (No. 50) & 405,8 & 1446 & 72,32 & 27,68 \\
\hline 0,15 & $\mathrm{~mm}$ & (No. 100) & 190,7 & 1637 & 81,86 & 18,14 \\
\hline 0,075 & $\mathrm{~mm}$ & (No. 200) & 226,5 & 1863 & 93,18 & 6,817 \\
\hline & pan & & 136,3 & 2000 & 100 & 0 \\
\hline Total bera & & & 1999 & & & \\
\hline
\end{tabular}




\section{Menentukan Komposisi Agregat Campuran HRS-} WC Alami

Pemeriksaan analisa gradasi bertujuan untuk mengetahui berat dan prosentase agregat yang lolos pada masing - masing saringan. Maka selanjutnya dihitung proporsi agregat dalam campuran dengan menggunakan metode grafis seperti pada grafik dan tabel komposisi campuran agregat dibawah ini:

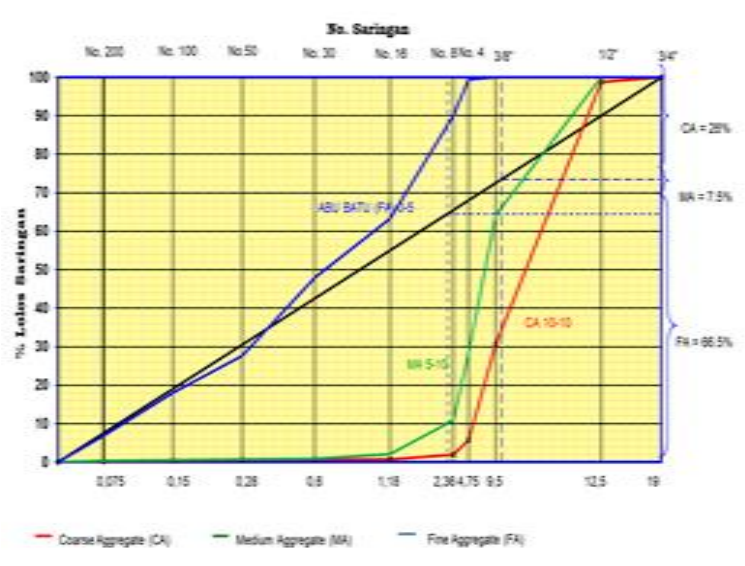

Gambar 3. Diagram Diagonal Komposisi Campuran Agregat Alami

Setelah proporsi masing-masing agregat diketahui yang dapat dilihat pada gambar 3. Maka dilanjutkan menyusun komposisi campuran untuk agregat dan aspal.

Lalu dilakukan pembuatan benda uji melalui proses pemanasan, pengadukan, dan pemadatan antara campuran agregat alami dan aspal (sesuai dengan SNI 06-2489-1991). Setelah itu pengujian marshall. Untuk diketahui kadar aspal optimumnya. Berikut hasil perolehan data dari setiap parameter marshall berupa diagram batang menggunakan acuan Spesifikasi umum Bina Marga 2018 :

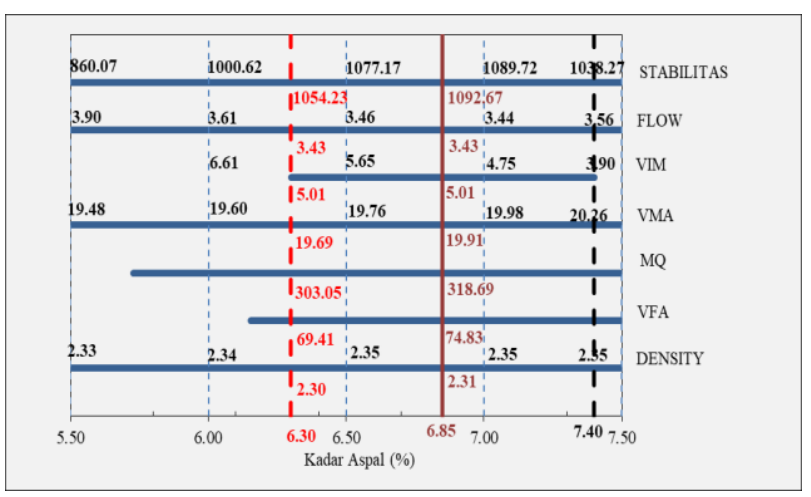

Gambar 4 Diagram Batang Kadar Aspal Optimum Agregat Alami

Dari diagram batang diatas maka didapatkan nilai Kadar Aspal Minimum sebesar 6,30 \%, dan Kadar Aspal Maksimum 7,40 \%. Lalu penentuan Kadar aspal optimum ini didapatkan berdasarkan nilai rata rata minimum serta maksimum sehingga didapatkan Kadar Aspal Optimal (KAO) sebesar 6,85\%.

\section{Menentukan Komposisi Agregat Campuran HRS- WC Pasir Pantai Sipelot}

Pemeriksaan analisa gradasi bertujuan untuk mengetahui berat dan prosentase agregat yang lolos pada masing - masing saringan. Maka selanjutnya dihitung proporsi agregat dalam campuran dengan menggunakan metode grafis seperti pada grafik dan tabel komposisi campuran agregat dibawah ini:

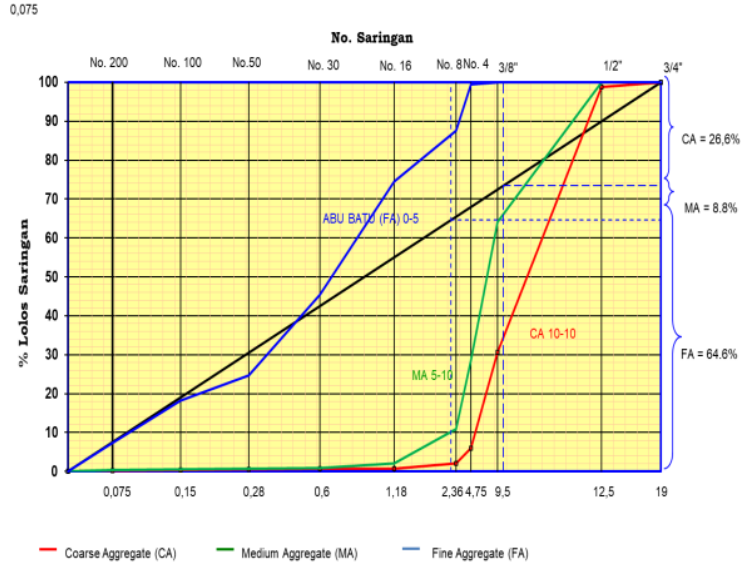

Gambar 5. Diagram Diagonal Komposisi Campuran Agregat Pasir Pantai Sipelot

Setelah proporsi masing-masing agregat diketahui yang dapat dilihat pada gambar 5. Maka dilanjutkan menyusun komposisi campuran untuk agregat dan aspal.

Lalu dilakukan pembuatan benda uji melalui proses pemanasan, pengadukan, dan pemadatan antara campuran agregat pasir pantai Sipelot dan aspal (sesuai dengan SNI 06-2489-1991). Setelah itu pengujian marshall. Untuk diketahui kadar aspal optimumnya. Berikut hasil perolehan data dari setiap parameter marshall berupa diagram batang menggunakan acuan Spesifikasi umum Bina Marga 2018 :

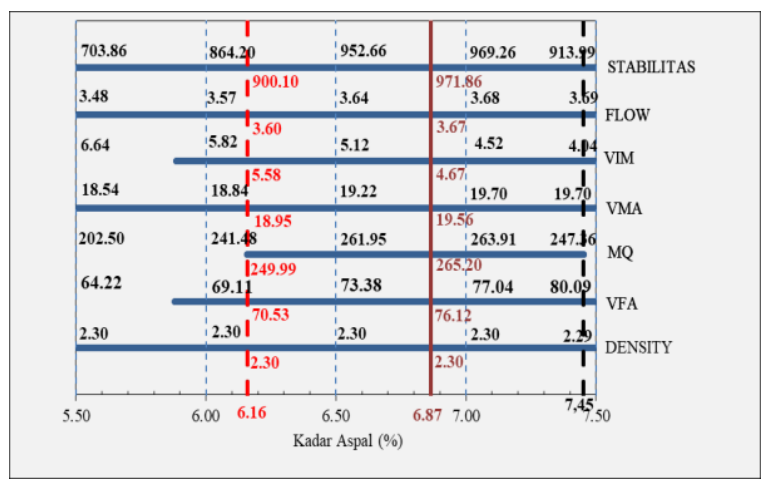

Gambar 6 Diagram Batang Kadar Aspal Optimum Agregat Pasir Pantai Sepelot 
Dari diagram batang diatas maka didapatkan nilai Kadar Aspal Minimum sebesar 6,16\%, dan Kadar Aspal Maksimum 7,45\%. Lalu penentuan Kadar aspal optimum ini didapatkan berdasarkan nilai rata rata minimum serta maksimum sehingga didapatkan Kadar Aspal Optimal (KAO) sebesar 6,87\%.

\section{Komposisi Campuran Variasi}

Tahap rancangan campuran di Laboratorium, Proporsi variasi campuran Pasir Pantai Sipelot dengan kadar variasi campuran 25\%, 50\% dan $75 \%$.

Berikut hasil setiap parameter Marshall dengan Variasi campuran Pasir Pantai Sipelot dan Alami:

\section{Stabilitas}

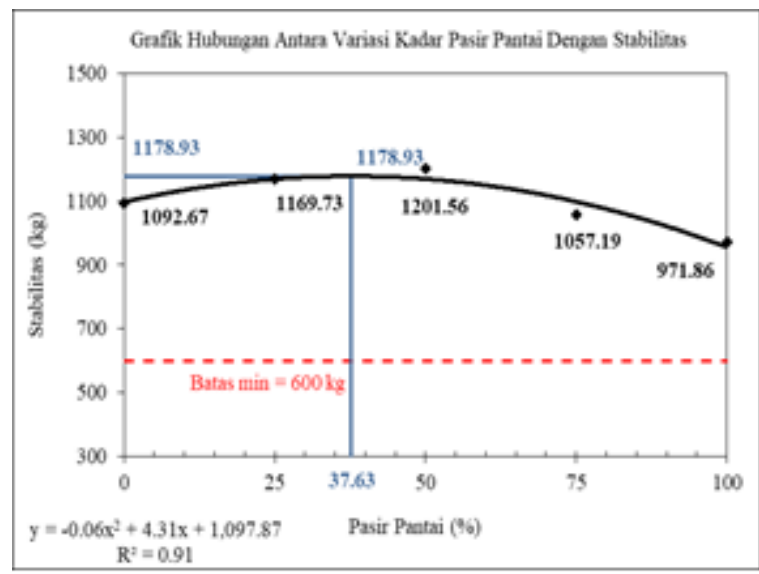

Gambar 7 Hubungan Antara Kadar Variasi Pasir Pantai Sipelot dengan Stabilitas

Stabilitas adalah kemampuan perkerasan jalan untuk menahan beban lalu lintas tanpa mengalami perubahan bentuk tetap seperti gelombang, alur, dan bleeding. Dari hasil penelitian yang dilakukan stabilitas sendiri sebenarnya dipengaruhi oleh penambahan jumlah kadar pasir pantai 25\%, 50\%, 75\%. Dari gambar 7 hubungan antara variasi kadar pasir pantai dengan stabilitas dapat dilihat bahwa nilai stabilitas mengalami kenaikan pada variasi $25 \%$ dan $50 \%$ masing-masing sebesar $1169,73 \mathrm{~kg}$ dan $1201,56 \mathrm{~kg}$, akan tetapi variasi untuk $75 \%$ pasir pantai mengalami penurunan sebesar $1057,19 \mathrm{~kg}$. Nilai stabilitas maksimum pada variasi kadar pasir pantai $25 \%$ hingga $100 \%$ tercapai pada saat variasi kadar pasir pantai $50 \%$ yaitu sebesar $1201,56 \mathrm{~kg}$. Dilihat dari buku Spesifikasi Umum Bina Marga tahun 2018 tentang ketentuan sifat-sifat campuran lataston bahwa nilai stabilitas yang diperbolehkan atau minimum untuk lapisan permukaan / HRS-WC yaitu sebesar $600 \mathrm{~kg}$. Jadi, nilai stabilitas dari semua variasi kadar pasir pantai tetap masuk / memenuhi persyaratan yang telah ditentukan oleh Bina Marga.

\section{Flow}

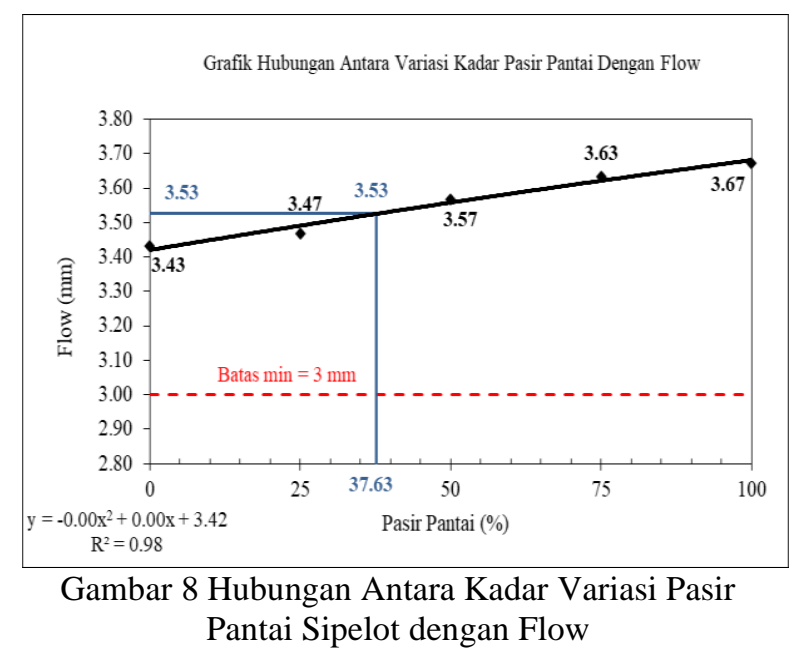

Kelelehan plastis (flow) merupakan besarnya perubahan bentuk plastis benda uji campuran beraspal yang terjadi akibat menahan suatu beban yang diterimanya. Berdasarkan Gambar 8 hubungan antara variasi kadar pasir pantai dengan flow dapat diketahui bahwa pada penggunaan pasir pantai dimulai dari variasi kadar $25 \%$ nilai flow sebesar 3,47 mm hingga $100 \%$ nilai flow sebesar 3,67 mm, Maka dapat disimpulkan semakin besar kadar pasir pantai nilai flow semakin tinggi. Menurut spesifikasi yang dikeluarkan oleh Bina Marga Prov. Jatim 2018 mengenai ketentuan yang menjelaskan tentang sifatsifat campuran lataston nilai flow minimum untuk lapis $H R S$ - $W C$ yaitu $3 \mathrm{~mm}$, sehingga dari keseluruhan nilai flow yang didapatkan dalam variasi Kadar pasir pantai $25 \%$ hingga $100 \%$ telah memenuhi persyaratan.

\section{VIM}

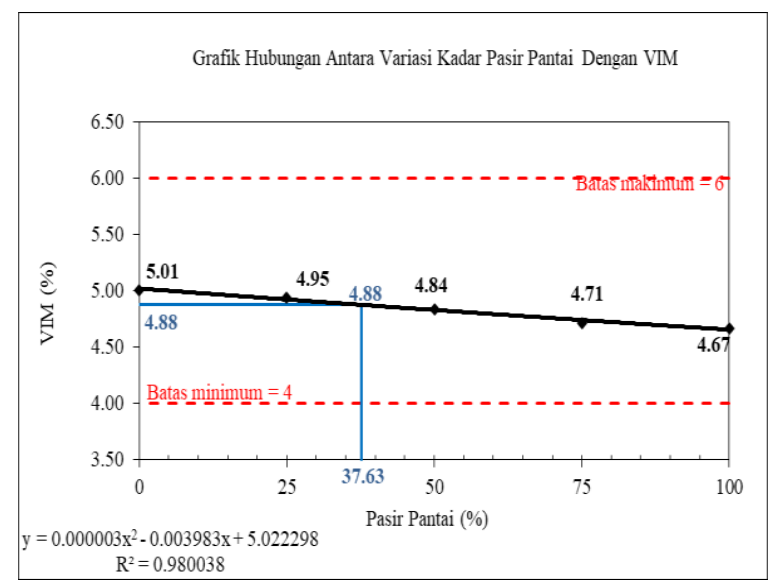

Gambar 9 Hubungan Antara Kadar Variasi Pasir Pantai Sipelot dengan VIM

Nilai VIM (Void In the Mix) merupakan nilai yang menunjukkan jumlah rongga dalam campuran. Nilai VIM berpengaruh terhadap keawetan dari campuran aspal tersebut, semakin tinggi nilai VIM 
menunjukkan semakin besar rongga dalam campuran, sehingga campuran bersifat porous (impermeable). Sedangkan nilai VIM yang kecil akan memberikan campuran yang lebih kedap air sehingga akan meningkatkan kemampuan campuran. Namun nilai VIM harus sesuai dengan persyaratan yaitu 4-6\%. Pada Gambar 9 menunjukkan bahwa pada penggunaan pasir pantai mengalami penurunan ketika penggunaan pasir pantai semakin besar. Dimana pada penggunan pasir pantai $25 \%$ didapatkan nilai VIM $4,95 \%$ dan semakin menurun $4,67 \%$ pada penggunaan pasir pantai $100 \%$. Variasi campuran dengan $25 \%$ pasir pantai lebih besar dibandingkan dengan variasi $100 \%$. Nilai VIM dari semua benda uji dengan penggunaan pasir pantai dan tanpa menggunakan pasir pantai tetap memenuhi persyaratan DPU Bina Marga 2018.

\section{VMA}

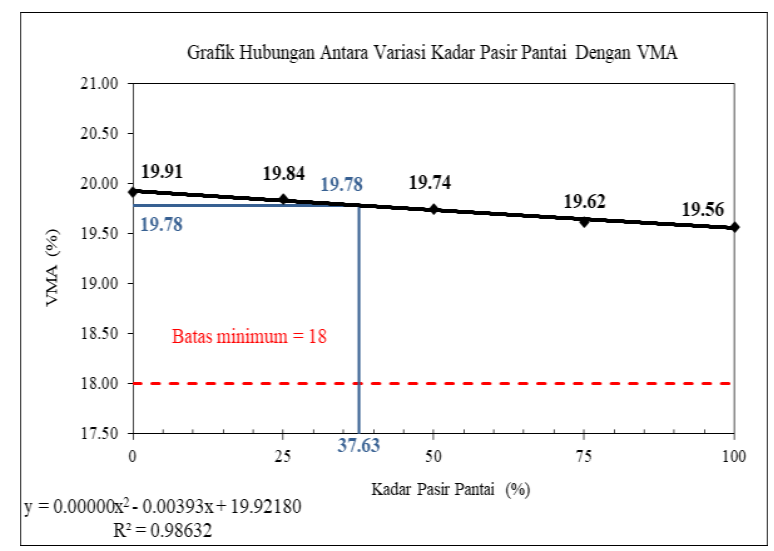

Gambar 10 Hubungan Antara Kadar Variasi Pasir Pantai Sipelot dengan VMA

Nilai VMA (Voids in the Mineral Aggregat) merupakan nilai yang menyatakan banyaknya rongga diantara butir-butir agregat di dalam beton aspal padat, yang dinyatakan dalam nilai persen. Namun nilai VMA harus sesuai dengan persyaratan yang telah ditentukan oleh DPU Bina Marga tahun 2018 yaitu batas minimum 18\%. Berdasarkan Gambar 10 hubungan antara variasi kadar pasir pantai dengan VMA menunjukkan nilai VMA semakin berkurang dengan seiring bertambahnya variasi kadar pasir pantai, dimana pada penggunaan variasi pasir pantai $25 \%$ dapat dilihat nilai VMA sebesar $19,84 \%$ dan terus mengalami penurunan sebesar $19,56 \%$ pada penggunan variasi pasir pantai $100 \%$. Nilai VMA dari semua benda uji dengan penggunaan pasir pantai dan tanpa menggunakan pasir pantai memenuhi persyaratan DPU Bina Marga 2018.

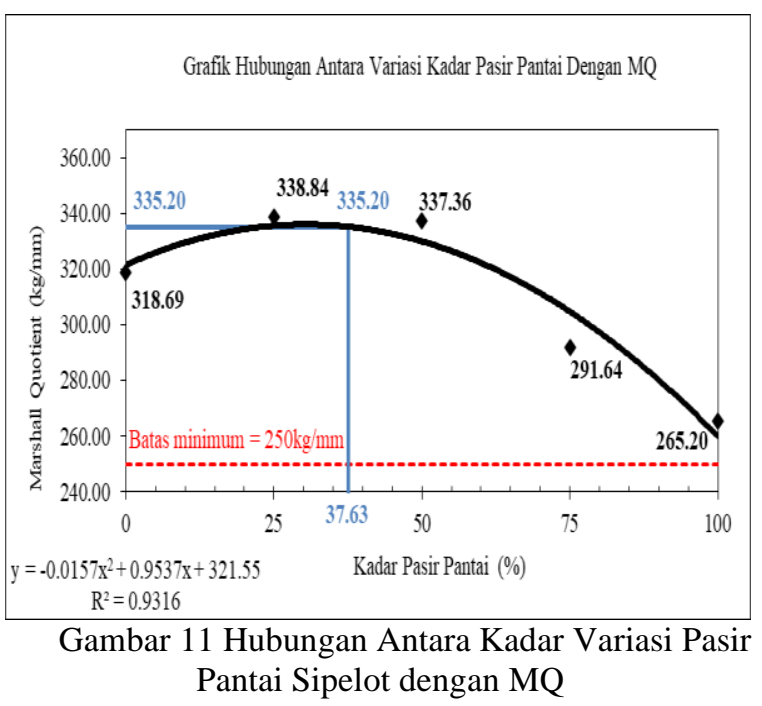

Marshall Quotient (MQ) merupakan hasil bagi antara stabilitas dengan kelelehan (flow). Berdasarkan Gambar 11 hubungan antara variasi kadar pasir pantai dengan $M Q$ dapat diketahui bahwa pada variasi kadar pasir pantai $25 \%$ nilai $M Q$ sebesar $338,84 \mathrm{~kg} / \mathrm{mm}$ dan terus mengalami penurunan hingga pada variasi $100 \%$ didapatkan nilai $M Q$ sebesar 265,20 kg/mm. Hal ini disebabkan karena semakin bertambahnya kadar variasi pasir pantai sebagai pengganti agregat $0 / 5$ pada lapis permukaan / $H R S-W C$ maka nilai $M Q$ pun akan semakin mengalami penurunan. Nilai $M Q$ tertinggi atau maksimum dalam variasi berada pada kadar variasi pasir pantai $25 \%$ dengan nilai $338,84 \mathrm{~kg} / \mathrm{mm}$. Dengan hasil ini nilai Marshall Quotient dari semua benda uji yang telah dibuat dan dilakukan tes masih memenuhi persyaratan yang ditetapkan oleh DPU Bina Marga 2018 dikarenakan batas minimum untuk nilai $M Q$ adalah $250 \mathrm{~kg} / \mathrm{mm}$.

\section{VFA}

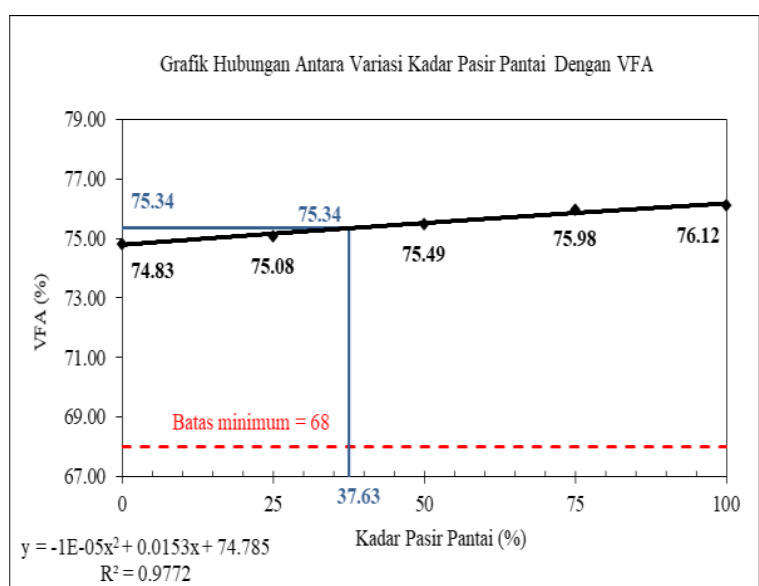

Gambar 12 Hubungan Antara Kadar Variasi Pasir Pantai Sipelot dengan VFA

Void Filled with Asphalt / Prosentase rongga dalam campuran yang terisi aspal adalah presentase rongga 
dalam agregat padat yang terisi aspal. Untuk nilai $V F A$ yang terlalu tinggi dapat menyebabkan naiknya aspal ke permukaan saat suhu perkerasan tinggi. Berdasarkan Gambar 12 hubungan antara variasi kadar pasir pantai dengan $V F A$ dapat dilihat bahwa pada variasi kadar pasir pantai $25 \%$ hingga variasi kadar $100 \%$ nilai VFA mengalami peningkatan, sehingga dapat ditarik kesimpulan bahwa dengan bertambahnya variasi kadar pasir pantai sebagai pengganti agregat $0 / 5$ pada lapis permukaan / HRS$W C$ akan mengalami kenaikan dan mempengaruhi nilai $V F A$. Dari variasi kadar pasir pantai $25 \%$ hingga $100 \%$ dapat dilihat nilai $V F A$ tertinggi terdapat pada campuran kadar $100 \%$ dengan nilai sebesar 76,12\%. Berdasarkan hasil spesifikasi yang telah dikeluarkan oleh Bina Marga 2018 tentang ketentuan sifat-sifat campuran lataston nilai $V F A$ minimum untuk lapis $H R S-W C$ yaitu $68 \%$, sehingga dari semua benda uji dengan variasi kadar pasir pantai yang telah dibuat maka hasil dari $V F A$ telah memenuhi persyaratan yang telah ditentukan.

\begin{tabular}{|c|c|c|c|c|c|c|c|}
\hline \multirow{2}{*}{$\begin{array}{c}\text { Parameter } \\
\text { Karakteristik }\end{array}$} & \multicolumn{6}{|c|}{ Variasi Agregat Pasir Pantai (\%) } & \multirow{2}{*}{ Persyaratan } \\
\cline { 2 - 7 } & $\mathbf{2 5}$ & $\mathbf{3 7 . 6 3}$ & $\mathbf{5 0}$ & $\mathbf{7 5}$ & 100 & \\
\hline Stabilitas (Kg) & 1092.67 & 1169.73 & 1178.93 & 1201.56 & 1057.19 & 971.86 & Min 450 \\
\hline Flow (mm) & 3.43 & 3.47 & $\mathbf{3 . 5 3}$ & 3.57 & 3.63 & 3.67 & Min 3 \\
\hline VIM (\%) & 5.01 & 4.95 & 4.88 & 4.84 & 4.71 & 4.67 & 46 \\
\hline VMA (\%) & 19.91 & 19.84 & 19.78 & 19.74 & 19.62 & 19.56 & Min 18 \\
\hline VFA (\%) & 74.83 & 75.08 & $\mathbf{7 5 . 3 4}$ & 75.49 & 75.98 & 76.12 & Min 68 \\
\hline $\begin{array}{c}\text { Marshall Quotient } \\
\text { (Kg } / \mathrm{mm})\end{array}$ & 318.69 & 338.84 & $\mathbf{3 3 5 . 2 0}$ & 337.36 & 291.64 & 265.20 & Min 250 \\
\hline
\end{tabular}

Tabel 12. Hasil Rekapitulasi Analisis Karakteristik Campuran Pasir Pantai dengan Variasi Kadar Pasir Pantai 25\%, 50\%,75\% dan $100 \%$ dan Persentase Optimum Pasir Pantai 37,63\%.

Dari hasil pengujian pada variasi campuran Pasir Pantai Sipelot didapatkan nilai optimum pada variasi campuran $37,63 \%$.

\section{PENUTUP}

\section{Kesimpulan}

1. Berdasarkan hasil penelitian yang telah dilakukan didapat bahwa penggunaan pasir pantai Sipelot sebagai pengganti agregat $0 / 5$ pada lapis $H o t$ Rolled Sheet-Wearing Course (HRS-WC) dapat mempengaruh nilai karakteristik Marshall. Dari pengujian hipotesis menunjukkan bahwa ada pengaruh yang signifikan terhadap Stabilitas 21,30>3,48 Ha diterima Ho ditolak, VIM 46,569>3,48 Ha diterima Ho ditolak, VMA $66,612>3,48$ Ha diterima Ho ditolak, MQ 10,077>3,48 Ha diterima Ho ditolak, VFA 41,996>3,48 Ha diterima Ho ditolak, namun flow $0,959<3,48$ Ha ditolak Ho diterima dan tetap memenuhi spesifikasi Bina Marga Jawa Timur $2018 \%$
2. Dari hasil pengujian Marshall nilai persentase optimum penggunaan pasir pantai terdapat pada kadar variasi $37,63 \%$ dengan nilai stabilitas sebesar $1178,93 \mathrm{~kg}$, flow 3,53 mm, VIM 4,88\%, VMA $19,78 \%$, MQ $338,84 \mathrm{~kg} / \mathrm{mm}$ dan VFA $75,34 \%$

\section{Saran}

Untuk penelitian lebih lanjut, disarankan untuk :

1. Untuk penelitian selanjutnya harap melakukan pengujian Soundness test/pelapukan untuk mengetahui kekekalan agregat terhadap pengaruh cuaca.

2. Karakteristik pasir pantai disetiap daerah belum tentu sama, maka dicoba membandingkan dengan pasir pantai lain.

\section{DAFTAR PUSTAKA}

Anonim. Buku Panduan Pratikum Bahan Jalan Institut Teknologi Nasional Malang. Malang.

Arifiardi, 2016. Pengaruh Penggunaan Pasir Pantai Carita Sebagai Campuran Agregat Halus Pada Lapisan Permukaan Aspal Beton Terhadap Persyaratan Parameter Marshall. Banten

Aufi Shabrina, 2019. Analisis Pemanfaatan Pasir Pantai Kemala Sebagai Bahan Tambah Campuran Asphalt Concrete - Wearing Course $(A C-W C)$. Surakarta

Direktorat Jendral Bina Marga. 1987. Departemen Pekerjaan Umum RI Petunjuk Pelaksanaan Lapis Aspal Beton Untuk Jalan Raya SKBI-2.3.26PU. Jakarta

Direktorat Jendral Bina Marga. 2018. Spesifikasi Umum Untuk Pekerjaan Konstruksi Jalan Dan Jembatan. Jakarta

Hanindya Fatihatun Najihan, 2019. Pengaruh Penggunaan Pasir Pantai Sebagai Bahan Pengganti Agregat Halus Dengan Penambahan Filler Abu Tebu Pada Campuran Aspal Terhadap Karakteristik Marshall. Yogyakarta

Pemerintah Provinsi Jawa Timur Dinas Pekerjaan Umum Bina Marga. 2018. Spesifikasi Umum Dinas Pekerjaan Umum Bina Marga Provinsi Jawa Timur. Surabaya.

Sudjana, 2002. Metode Statistika. Tarsito, Bandung.

Sugiyono, 2014. Statistika Untuk Penelitian. Alfabeta, Bandung

Sukirman, S. 1993. Perkerasan Lentur Jalan Raya. Nova. Bandung.

Sukirman, S. 1999. Perkerasan Lentur Jalan Raya. Nova. Bandung.

Sukirman, S. 2003. Beton Aspal Campuran Panas. Granit. Jakarta.

Sukirman, S. 2007. Agregat. Granit. Jakarta 
